\title{
The role of spirituality and Africana womanism in the self-management of chronic conditions among older African Americans
}

\author{
I dethia Shevon Harvey \\ Human Development and Family Studies, University of Connecticut, USA \\ Correspondence: Idethia Shevon Harvey. Address: 348 Mansfield Road, Unit 1058, USA. Email: \\ Idethia.harvey@uconn.edu. \\ Received: January 3, $2013 \quad$ Accepted: March 13, $2013 \quad$ Online Published: May 20, 2013 \\ DOI : $10.5430 /$ jnep.v3n12p81 \\ URL: http://dx.doi.org/10.5430/jnep.v3n12p81
}

\begin{abstract}
Background: Many older African Americans perceive "spirituality" as an important resource in helping with the self-management process of their chronic conditions. Research designs congruent with theoretical frameworks of African Americans are important. However, many researchers remain unfamiliar with Africana womanist thought or are unsure as to how this framework can be used to inform specific aspects of self-management practices.

Methods: The purpose of this exploratory study is to explain an Africana womanist epistemologic framework that can undergird the development of self-management intervention designs aimed at assisting older African Americans. Data from a sample of 46 African Americans were collected from semi-structured interviews and examined via thematic analysis.
\end{abstract}

Results: Concepts of Africana womanism epistemology, which can be interwoven throughout self-management strategies, include: 1) the importance of spirituality and 2) the ethic of personal responsibility.

Conclusions: Health care and public health professionals can assist in the co-creation of programs that focus on spirituality and the collective personal responsibility of health promotion practices.

\section{Key words}

African Americans, Self-management, Spirituality, Qualitative research

\section{I ntroduction}

According to the Department of Health and Human Services Administration on Aging ${ }^{[1]}$, in 2011, older minority Americans comprised 20\% of Americans 65 years and older. By 2050, the older minority population is projected to increase by $160 \%$, compared to a projected increase of $59 \%$ of non-Hispanic whites. In particular, the population of older African Americans is projected to increase from $8 \%$ to $11 \%$ of the total population by $2050^{[1]}$. The burden of disease is felt in two ways: a shorter life expectancy for African Americans and a prolonged interval of managing chronic conditions. As African Americans age, they are more likely to be diagnosed with a persistent condition and spend a greater portion of their remaining years with chronic conditions ${ }^{[2-4]}$. African Americans are more likely to have higher rates of hypertension and are more likely to die from cardiovascular disease than non-Hispanic whites ${ }^{[5]}$. In addition, African Americans are 1.8 
times more likely to develop type-2 diabetes than non-Hispanic whites, with 25\% of African Americans aged 55 years and older being diagnosed with this condition ${ }^{[6]}$. Finally, older African Americans are more likely to be diagnosed with knee osteoarthritis and have a higher burden of large joint osteoarthritis such as of the hip or spine, compared to non-Hispanic whites. For many older adults, living with a chronic condition signals a diminishing quality of life and becomes a balancing act as older adults must make daily decisions to manage adaptive behaviors ${ }^{[7]}$.

Health and well-being are a concern for most older adults. But for older African Americans, spirituality plays a major role in the recovery of both their physical and mental health. The use of spirituality in health-related research has gained renewed interest, particularly focusing on older African Americans adults ${ }^{[8]}$. A growing body of research indicates that strong spirituality is an important factor in the health and well-being of older African Americans, including selfmanagement of chronic illness ${ }^{[9,10]}$. Older African Americans hold strong spiritual beliefs upon which they often base their decisions in self-management practices ${ }^{[10,11]}$. However, several limitations have arisen regarding the scientific study of the relationship among aging populations, spirituality, and self-management practices. For example, most studies primarily use quantitative methods, but they lack heterogeneity among gender and racial/ethnic groups in examining the experiences of research respondents ${ }^{[12]}$. Although a number of authors have explored the importance of spirituality to selfmanagement behaviors ${ }^{[10,13]}$, using Africana womanism as a health behavior paradigm in the process of self-management practices has not been researched. The purpose of this study is to provide insight into the life experiences and health of chronically ill older African Americans through the lens of Africana womanism.

\subsection{Defining religion and spirituality practices}

"Religion" and "spirituality" have often been used interchangeably, yet these two terms are distinct and, in some cases, overlapping concepts ${ }^{[14]}$. Religion conveys the practice and conformity of religious rituals, beliefs, and procedures ${ }^{[15,16]}$. Accordingly, "religion," as defined by its boundaries, is an inclusive concept and narrow in scope. "Spirituality," on the other hand, can be defined as a relationship with a Higher Power that fosters a sense of meaning, purpose, and mission in life. In turn, this relationship produces altruism, love, or forgiveness that has a discernable effect on an individual's relationship to self, nature, others, and the ultimate ${ }^{[17,18]}$. Researchers have acknowledged that spirituality transcends religious boundaries and is the essence of an individual's well-being ${ }^{[19]}$. It is important to establish a working definition of spirituality that the author can systematically use to facilitate interdisciplinary dialogue. For the purpose of the study, "spirituality" is defined as the process of coming to a belief system, naming core values, and acting on them.

Spirituality is expressed in many forms and is present throughout the life course of African Americans as a way of giving meaning to their lives. Historically, African Americans' experiences are grounded in a background of healing traditions and practices that include spirituality ${ }^{[20]}$. Through years of coping with racial discrimination and socioeconomic challenges, African Americans use spirituality to maintain their health while dealing with the stressors embedded in the cultural realities of their lives ${ }^{[21,22]}$. Values and practices, as with prayer and regular church attendance, have become routine support mechanisms in dealing with adversity, such as racism and poverty ${ }^{[21]}$. Likewise, African Americans' "belief in an ever-present divine power capable of delivering them from any measure of trouble has been a traditional characteristic of their faith" (p. 48) ${ }^{[23]}$. This belief or ethos of spiritual practice of resistance instills in African Americans a power of determination and optimism, while maintaining personal dignity and an unwavering love of God ${ }^{[24]}$.

\subsection{Self-management practices}

Clement ${ }^{[25]}$ defined "self-management" as the knowledge attained and skills required in 1) taking care of oneself, 2) being able to manage crises, and 3) changing one's lifestyle successfully. Clark et al. ${ }^{[26]}$ described three sets of tasks individuals must master to ensure successful self-management of chronic illness. First, the individual must be knowledgeable about her condition to determine the required care. Second, the individual must be able to perform activities to manage that condition. Third, the individual must apply skills essential to sustain adequate psychosocial functioning. In other words, self-management of chronic illness refers to day-to-day activities that individuals adopt to keep the illness under control, 
reduce its impact on their physical health status, and cope with the psychosocial consequence of the illness. Such activities often include, but are not limited to, medication management, physical activity, and dietary compliance.

\subsection{Self-management and spirituality}

Researchers have identified the importance of spirituality for African Americans in self-management practices ${ }^{\text {[27-32] }}$. Davis ${ }^{[32]}$ and McAuley et al. ${ }^{[30]}$ reported that African Americans believe that God is in control of illness and protects them from harm through praying and their faith. In addition, Mansfield et al. ${ }^{[29]}$ found that African Americans more commonly reported praying for guidance, help, or healing for self and others compared to non-Hispanic whites. Likewise, researchers have found that African Americans reported God worked through their doctors to help care for their conditions ${ }^{[29]}$. Loeb's study ${ }^{[28]}$ on older African American women identified several health behavior strategies to manage chronic illness: being involved in physical activity, seeking health information, relying on God, changing dietary patterns, observing medication compliance, and self-monitoring. Polzer and Miles ${ }^{[10]}$ found that African Americans diagnosed with type-2 diabetes relied heavily upon their spiritual beliefs to manage their condition. In addition, Loeb et al. ${ }^{[3]}$ and Loeb ${ }^{[28]}$ reported that respondents practiced a variety of health-promoting behaviors for their chronic conditions. Specific coping strategies included: relating with health care providers, medicating, exercising, changing dietary patterns, and seeking health information ${ }^{[33]}$. Recently, health care researchers used individual interviews to examine how disadvantaged middle- and late-life adults with multiple morbidities use self-management strategies for their chronic conditions ${ }^{[27]}$. The study's respondents disclosed the use of cognitive structure techniques, self-care regimens, and faith-oriented strategies. Although both races were consistent in self-care and cognitive structuring techniques, African Americans were more likely than non-Hispanic whites to mention prayer and receiving support from God and church members as strategies for selfmanagement ${ }^{[27]}$.

Studies indicate that spiritual practices may enhance self-management of chronic conditions in African Americans. Utz et al. ${ }^{[34]}$ and Jones et al., ${ }^{[35]}$ with sample sizes of 68 and 73 patients, respectively, conducted focus group interviews with African Americans with type-2 diabetes to identify barriers and facilitators to self-management. Respondents reported that faith in the Bible helped them decide what foods to eat. Furthermore, Samuel-Hodges et al. ${ }^{[31]}$ found that belief in God played a central, supportive role in the management of type-2 diabetes among African American women. African Americans and non-Hispanic whites viewed prayer as a major component of their self-management of chronic disease ${ }^{[28,33]}$. Forms of spirituality, such as praying or meditating, may help individuals cope with chronic illness. Spirituality may serve as an internal agency to perform behavioral changes to mediate the chronic condition.

\subsection{Africana womanist theory}

Hudson-Weems ${ }^{[36,37]}$ posited that Africana womanism arises from the African diaspora unique experience, and that its framework is family centered and race based. The Africana womanism's methodology examined one's own cultural roots and historical grounding. According to Hudson-Weems ${ }^{[36]}$, Africana womanism is an African-centered ideology created and designed for all individuals of African descent. It is grounded in the Afrocentric culture, focusing on the unique experiences, struggles, needs, and desires of the African diaspora while critically addressing the conflicts between itself and mainstream and Black feminist frameworks ${ }^{[36]}$.

Family-centered and "in concert with males in struggle" represent two of the 18 features that characterize the Afrocentric beliefs of the African American existence ${ }^{[37]}$. Other descriptors included being spiritual, nurturing, having flexible roles, and being male compatible ${ }^{[37]}$. The reconstruction of "their story" was important for understanding and defining African cultural identity outside Eurocentric paradigms ${ }^{[37,38]}$. Moreover, the researchers argued the shared responsibilities between males and females are central to Africana womanist thought. African American women therefore work together with African American men against racism and in other social arenas. Nursing researchers have done studies using Afrocentric frameworks to conduct and interpret research with African Americans ${ }^{[39]}$. Banks-Wallace ${ }^{[40]}$ used the African womanist theory in the exploration of storytelling as a research tool and intervention. It is important to acknowledge that both feminine and masculine realities were found within the African community concerning the complementarity of male 
and female. This African-centered concept viewed women and men as partners, different in their roles and assessments, but equal as human beings. Hudson-Weems has argued that Africana womanism "embraces the concept of collectivism for the entire family in its overall liberation struggle for survival” (p. 44) ${ }^{[36]}$. Subsequently, African American consciousness is filtered through the family and community. These views provide the foundation for incorporating the Africana womanism paradigm into African Americans' spirituality and health realities. The main purpose of this research is framing "spirituality" in this manner to give room to discover a new model within the existing Africana womanism framework. The research also provides a novel understanding of African Americans spirituality and health.

\section{Subjects and methods}

\subsection{Study design}

Phenomenology is a qualitative research method that allows the investigator to understand the lived experience of the respondents ${ }^{[41]}$ and to gain meaning from their everyday experiences ${ }^{[42]}$. In a phenomenological study, an in-depth interview is frequently used to collect data about a phenomenon. The interview enables the researcher to explore, gather the data, and develop a rich and deep understanding of the respondent's experience while engaging in a dialogue ${ }^{[42]}$. In-depth interviews were used to allow respondents to describe their experiences in a way that feels comfortable to them. Afrocentric scholars have promoted this qualitative methodology as their preferred research format in which they encourage the respondents to explore a deeper understanding of a specified phenomenon ${ }^{[43]}$. Africana womanism is a viable framework to use in this study because it places African Americans at the center of the analysis and allows researchers to explore the variables of race and gender from African Americans' unique socio-cultural-spiritual

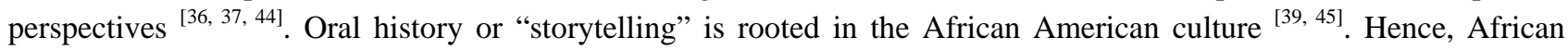
Americans may perceive participating in in-depth interviews as their opportunity to testify or bear witness to their realities.

\subsection{Sampling procedure}

Respondents were recruited from a larger study that examined self-care behaviors among adults diagnosed with hip/knee osteoarthritis or ischemic heart disease. Disease eligibility criteria were based on a series of self-report questions derived from the National Health and Nutrition Survey ${ }^{[46]}$ and self-report disease markers for cardiac conditions and treatments. Additional eligibility criteria included community-dwelling residents residing in southwestern Pennsylvania aged 65 and older who were able to give consent. The Institutional Review Board approved the current study in which respondents were asked to define "spirituality" and explain how their spirituality or spiritual beliefs helped them manage their illnesses. Demographic information (age, race/ethnicity, gender, and spiritual beliefs) was gathered at the beginning of the study. The sampling strategies focused on respondents who were considered experts on the phenomenon under study (i.e., self-identified as being very spiritual). Older African Americans who were willing to share their spiritual beliefs were invited to continue their dialogue regarding the self-management of their chronic conditions. Using the quota sampling technique, 46 older African American men and women were selected to receive additional questions on the topic of spirituality and self-management behaviors. We advised the participants prior to the interview that their involvement was voluntary and that they could stop the interview at any time without penalty.

Using a 4-point Likert scale, respondents were asked the following question: "To what extent do you consider yourself a spiritual person?" The interviewers were trained to use this question as a prompt in the qualitative study. They asked the respondents: "You said you were ['very' or 'moderately'] spiritual. There are many ways that people define 'spirituality.' It can mean different things to different people. We would like to know what does being 'spiritual' mean to you?” After ascertaining the respondents' definition of "spirituality," these adults were subsequently asked: "You also mentioned that your most important health problem is People have told us many different ways that their spirituality or spiritual beliefs have helped them with their most important health problem. Can you tell me how your spiritual beliefs or feelings about spirituality have helped you?” 
The questions focused on the respondent's experience with spirituality, the personal meaning of spirituality for the respondent, and the role of spirituality in that individual's self-management behavior. Throughout the interview, the interviewers followed each respondent's lead by allowing subsequent questions to be guided by the respondent's answers. For instance, if the respondent used words such as "prayer" or "God" to describe their practice of spirituality, the author incorporated that word into the subsequent questions. After receiving permission from the respondents, all interviews were audio-recorded during the face-to-face interaction. The average time for each interview lasted approximately 2.5 hours. Confidentiality procedures involved removing all identifying information associated with the participants; all interview information plus the study's tapes and transcripts were placed in a locked file. To guarantee anonymity and confidentiality, tapes and transcripts were assigned identification numbers. Only authorized project personnel had access to the information.

\subsection{Data analysis}

\section{Quantitative data analysis}

Demographic data were entered and analyzed using the Statistical Package for the Social Sciences (v20). Descriptive statistics were used to report the demographics of respondents.

\section{Qualitative data analysis}

This study utilized deductive or "theoretical" thematic analysis to identify, analyze, and report patterns for understanding the meanings of "Africana womanism" and "spirituality," as they relate to self-management practices among aging African Americans in an urbanized city ${ }^{[47,48]}$. In addition, the analysis was centered within the womanism paradigm to explore the interconnections of spiritual beliefs and self-management practices. Using the Africana womanist paradigm as a guide ${ }^{[45]}$, data analysis provided a more meaningful examination and interpretation of African Americans' experiences because this perspective acknowledged that respondents are experts regarding their experiences with chronic conditions.

Each interview was professionally transcribed verbatim. Particular attention was paid to retaining the individual respondent's voice by writing excerpts in the respondent's own words. The transcribed data were read several times. This process of "repeated reading" ${ }^{[48]}$ was used to help the researchers become immersed in the interview. The next steps involved systematically generating initial codes from the transcription by using line-by-line coding of the transcripts. Initial descriptive coding, as well as using the words or phrases of the respondents, involved searching for repetition within and across the transcripts. These codes that were identified were considered pertinent to the research question and theoretical concepts. The units of text were compared and sorted into categories and subthemes, which represented Africana womanism, spirituality, and self-management practices, as well as the chosen phenomena ${ }^{[49]}$. For the purpose of this inquiry, themes were identified as categories that connected elements of the narratives identified in the individual and collective transcripts. Themes were attributed to the group, rather than to individuals, as the unit of analysis.

After the coding process was completed for each transcript, the author examined subthemes to identify common concepts that illustrated the core categories of womanism. All initial codes relevant to the research question and theoretical concepts were incorporated into a subtheme. The identification of the subthemes and aspects in the narratives informed the researcher how older urbanized African Americans used the precepts of Africana womanism and spirituality to manage their chronic conditions. Confidentiality was maintained in the interviews and the individuals (i.e., interviewee and their social relationships) were given pseudonyms.

Procedures were used to establish the trustworthiness of data and the findings ${ }^{[50]}$. Data saturation of the interviews addressed credibility of the findings. The researcher proceeded as follows: 1) established transferability through the interpretations of the data; 2) made an effort to conduct external checks of the findings with current literature ${ }^{\text {[39]; }}$ 3) determined confirmability, which supports objectivity, by listening to audiotapes of the interviews, reading field notes, and checking detailed records on the coding schema; and 4) made certain that dependability occurred by using the same 
data collection protocol for the in-depth interviews and by independent researchers reviewing and critiquing the analysis and interpretation of the data ${ }^{[51]}$.

\section{Findings}

\subsection{Demographic characteristics}

Table 1 compares African American male and female respondents in the qualitative sample. The qualitative cohort, by design, included roughly equal numbers of males $(n=25)$ and females $(n=21)$. For men, the mean age was 75.1 years (SD $=4.6)$ and for women, the mean age was 72.4 years $(\mathrm{SD}=4.9)$. For both genders, men $(64 \%)$ and women $(43 \%)$ were married. However men were more likely to be widowed (28\%) while women were more likely to be separated or divorced (33\%). Women were more likely to have some form of post-secondary education (38\%) or bachelor's degree (19\%) while less than one quarter (24\%) of men had a college degree. Both male and female respondents stated cardiovascular disease as their most important chronic condition, $51 \%$ and $48 \%$ respectively. Male respondents also reported diabetes (20\%), other illness (16\%) and arthritis (13\%) as the important chronic conditions. Other conditions reported by female respondents were diabetes and complications due to diabetes (24\%), arthritis (14\%), and other illness (14\%). An overwhelming majority (96\%) of men identified as being Protestant and reported having either "very high" or "moderate" levels of spirituality (80\%). Religious affiliation among women was recorded as being Protestant (81\%), Catholic (14\%), and other (5\%), and they reported having either "very high" or "moderate” levels of spirituality (90\%).

Table 1. Sociodemographic Characteristics $(\mathrm{N}=46)$

\begin{tabular}{lll}
\hline Characteristics & Males (N = 25) & Female (N = 21) \\
\hline Age, mean (S.D.) & $75.1(4.6)$ & $72.4(4.9)$ \\
Marital Status \%, (N) & & \\
$\quad$ Single & $4(1)$ & $5(1)$ \\
$\quad$ Married & $64(16)$ & $43(9)$ \\
$\quad$ Widowed & $28(7)$ & $19(4)$ \\
$\quad$ Separated/Divorce & $4(1)$ & $33(7)$ \\
Education \%, (N) & $76(19)$ & $43(9)$ \\
$\quad$ High school or less & $16(4)$ & $38(8)$ \\
$\quad$ Some college & $8(2)$ & $19(4)$ \\
$\quad$ Bachelor or higher & $51(13)$ & $48(10)$ \\
Chronic Conditions & $20(5)$ & $24(5)$ \\
$\quad$ Cardiovascular disease & $16(4)$ & $14(3)$ \\
$\quad$ Type-2 diabetes & $13(3)$ & $14(3)$ \\
$\quad$ Other illness & & \\
$\quad$ Osteoarthritis & $96(24)$ & $81(17)$ \\
Religious Affiliation & 0 & $14(3)$ \\
$\quad$ Protestant & $4(1)$ & $5(1)$ \\
$\quad$ Catholic & & \\
$\quad$ Other & $36(9)$ & $52(11)$ \\
Spiritual Level & $44(11)$ & $38(8)$ \\
$\quad$ Very & $20(5)$ & $10(2)$ \\
$\quad$ Moderately & & \\
Slightly & &
\end{tabular}

\subsection{Themes}

African womanism assumes a holistic perspective that recognizes the uniqueness and complexity of older African Americans' experiences. For research purposes, only those themes that demonstrated the interconnectedness of the 
African Americans' beliefs about Africana womanism as a paradigm for spirituality and self-management will be presented. Concepts of Africana womanism epistemologies, which are interwoven throughout self-management strategies, include: 1) the importance of spirituality and 2) the ethic of personal responsibility. Examples of thematic results from transcribed interviews used verbatim wording.

\subsection{The importance of spirituality}

The first theme related with the characteristics from the African womanism paradigm is spirituality ${ }^{[37]}$. Both male and female respondents discussed how their experiential knowledge related to their spirituality and what role spirituality played in their health care. In addition, this theme described the respondents' belief in a Higher Power to intercede for a favorable outcome. For example, an 85-year-old male suffering from venous thrombosis described how he wavered with telling the receptionist that he thought he was having a potential heart attack:

I was sitting in the office of my urologist, and these pains, severe pains, started hitting me in the chest. And, to my mind I was sitting there, the more severe the pains became. And so I eventually [I said to myself] had to leave. I told the receptionist at the window I wanted to leave. ... I had to go. And so she made arrangements to tell the doctor.

In the reception area, the male respondent continued to describe his internal struggle between leaving or staying when he described how God intervened.

The doctor would not let me leave out on my own. He made arrangements for me to be transported across the way through the hospital to the emergency room where they treated me and come to the conclusion that it wasn't a heart attack that I was having [blood] clots. And they came to that conclusion, and they tried-they did make arrangements to administer the drugs to dissolve the clots as soon as possible. And it was through God's will that - that he instilled in the minds of the technicians who saved me and to work with me to dissolve these clots.

Similar to the male respondent, the views and actions were often based on the respondents' spiritual and health beliefs, which were consistently being re-assessed and re-evaluated. A 75-year-old female dialysis patient powerfully demonstrated the struggle between complying with her health care treatment plan versus stopping treatment and how her spirituality factored into her management of this struggle.

I know that if I do not go to dialysis and get the treatments like I'm supposed to, if I miss them, I'm going to die. Because the poisons are going to form up in my system and I won't live. Now I know that. I know enough about dialysis to know that.

The same respondent acknowledged that she struggled with her treatment plan.

So, I go. I go get my treatments. I don't feel like going every three times a week. I'm tired of them sticking them needles in me. I am sick and tired of lying down on that machine for three hours, three and a half hours, three times a week. I get very, very upset. I get upset when I go. I get upset when I come home. But I know that I have to go, so I go.

At this moment, her belief (i.e., spirituality) gives her the strength to continue with her dialysis treatments.

It [my spiritual beliefs] gives me more strength to go. Like I just got through telling you, I do not want to go. I do not want to go. I don't want ... like tomorrow morning, when it's time for me to get up and get dressed and go, I know I'm not going to want to go, but I wake up every day, it means the Lord came by and woke me up. And most of the time He will take care of everything. ... And He's going to take care of everything. . . And that's why I go every... three times a week. I tell the kids I've got to go. 
Because the respondents are sharing their personal experience as a basis of knowledge development, older African Americans can shape a culturally specific self-management program to implement in the future.

\subsection{Ethic of personal responsibility}

The second major theme centered within the African womanism paradigm is that of personal responsibility. While the previous theme placed great emphasis on a Higher Power-forces outside of oneself-this second theme of personal responsibility focused on the defined obligation of taking care of one's health. This theme described the respondents' spiritual and religious beliefs in their own capacity to execute specific actions required for a favorable outcome. Medical adherence and setting health limits were all considered important parameters in taking personal responsibility for one's self-management practices. In accordance with the role of spiritual beliefs, several women spoke of their body as a vehicle for their faith or as it being a "temple." For example, a married woman, diagnosed with cardiovascular disease, described the role of healthy dietary habits in her cardiovascular health outcomes. She was aware that a healthy diet could positively influence her heart, and she was also keenly aware of the possible deleterious impact of making the "wrong” eating choices:

And so I am not to eat or drink in excess anything that's going to harm it [heart]. I know that too much of certain foods would cause flak in my body, salt to retain fluid, and —not that I don't sometimes eat pretzels and stuff. . . . But in general, that I am to take care of-this is what all-this is how God can use me through a healthy body better than an unhealthy body.

Similarly, another female respondent acknowledged that God gave her the Bible as her “diet plan”.

Well, like I say, I believe God has given us a diet. And he told us what to eat and what we should eat and not to eat. When he put Adam and Eve in that garden, he told them ... you know, gave them all the vegetables and everything and told them to eat those things. And nuts and grains and fruits and vegetables and stuff. Those things we know are good for us. But now, like I said, we can mess up by abusing those things and not doing those things. It's not that God didn't tell us how to do it in the first place. It's our problem. But I believe if we follow him and live this diet and even taking care of our bodies by getting enough rest and, you know, eating the right things.

Personal responsibility also required experiencing suffering in order to participate in health-promoting behaviors, such as being compliant with the health care provider's instructions. One female participant with arthritis believed it was her personal responsibility to become proactive in her health care. She stated during the interview that when she spoke to God, He told her what she needed to do for her pain:

I just take it for granted, get up and go with it. And I'm going to see a doctor about it, but I know that some way, somehow, God will help me until I get to that doctor.

Although not verbose, several male respondents made the same kinds of comments when they reported their belief in the importance of their spirituality in empowering them to practice in health-promoting activities. An exemplar statement came from a 79-year-old male diagnosed with hypertension and type-2 diabetes.

My opinion, I am even more dependent on my daily guidance and asking for guidance for the day and for healing and help with my health and give me good gumption in how to take care of myself. Overall, I mean. ... the Lord helps them who help themselves.

\section{Discussion}

The African womanist theory was used to provide understanding and unique insight into self-management practices among older African Americans. This analysis attempted to elicit the relationship between the African womanist theory and spiritual beliefs among older adults in this study. In the case of African American older adults, the Africana womanist 
theory can provide a productive groundwork for the advancing the phenomenon within a unique culturally-based framework that has shaped the Afrocentric belief and value systems. The goal of the study was to understand the complexity of African Americans' lives as they manage and understand their chronic conditions through their spiritual beliefs. These findings were based on an African womanist paradigm that produced positive behavioral change, as well as providing a pathway for their spiritual faith ${ }^{[37,45,52,53]}$. It important to acknowledge that the statements based on both feminine and masculine realities were grounded in cultural traditions found within the African community.

For the older adults in this study, spirituality represented a personal belief and faith and/or a relationship with a Higher Power, identified as God or Jesus. The respondents' journey with self-management they contended begins with a personal relationship with God. They stated that their faith provided then the strength to make critical health behavioral changes to manage their chronic conditions. Self-management practices from the respondents drew strength based on African womanist paradigms, such as spirituality and adaptability. The older adults' experiences, as heard in their testimonies and in their application of Biblical narratives to their testimonies, suggest a consciousness that has enabled the respondents to maintain and sustain their health behavior changes ${ }^{[54]}$. Each of the respondents in this study told "their story" of a spiritual growth that transcended their current life experiences. Similar to Abrums ${ }^{[55,56]}$, the author found that spiritual beliefs offer insight based on the respondents' personal experiences. The practice of the "worship" experience allows for oral communication in the form of testimony, which is conducive to the edification of those who are present, the listeners and witnesses to the testimony ${ }^{[57]}$.

African Americans' religious groups have focused on valuing personal experiences, interpersonal relationships, and the establishment of community ${ }^{[58,59]}$. A crucial belief among these groups is that knowledge-sharing among individuals can be used to build or nurture behavioral change ${ }^{[60]}$. African womanist concepts, such as community building, selfdetermination, and empowering the older respondents through their interpersonal connections ${ }^{[61]}$ to make their behavioral changes, can be used to guide the development of future self-management interventions ${ }^{[62-65]}$. Although the intervenetions ${ }^{[62,63]}$ do not use African womanism within the study design, they draw upon its tenets by incorporating spiritual beliefs and practices, extended family network support systems, and a shared tradition of strength—all of which may serve to promote, maintain, and sustain health ${ }^{[64]}$. Self-management programs should include identification of cultural values associated with practices that are health-promoting for African Americans because these programs employ personal experiences as a basis for program development.

While this research study was limited to a small number of older adults and therefore is exploratory in nature, it provides the first step of inquiry, linking Africana womanism, spirituality, and self-management of chronic illness. Additional limitations to the study include the single geographic location and heavily Protestant religious beliefs. Nevertheless, the findings add to the limited research using the Africana womanist paradigm among older African American adults with chronic illness. Research is also needed to explore how other models can work in tandem with traditional medical and health behavior theories. Regardless of previous limitations, it is worth noting that this study expands the knowledge base of older African Americans' lived experiences, which is inspired by their spiritual beliefs and a way of identifying their commitment to the community ${ }^{[66]}$. This research study valued the older respondents' comments and reflections in the existing literature surrounding Africana womanist theory. This information is grounded in the consciousness that "one's well-being is connected with the well-being of others" (p. 41) ${ }^{[39]}$. In conclusion, although self-management has emerged as an important component of health maintenance, prevention, and illness management in recent decades, the cultural components of self-management and their relevance for illness management need further research.

\section{Acknowledgement}

The research reported in this paper was supported by the National Institute of Aging, Research Supplement for Underrepresented Minorities grant R 01 AG 18308. 


\section{References}

[1] Department of Health and Human Services Administration on Aging. Profile of older Americans, 2010. 2011.

[2] Odedina F, Dagne G, Pressey S, et al. Prostate cancer health and cultural beliefs of black men: The Florida Prostate Cancer

Disparity Project. Infectious Agents and Cancer. 2011; 6(2): S10-S17. PMid:21992652

http://dx.doi.org/10.1186/1750-9378-6-S2-S10

[3] Tinetti ME, McAvay GJ, Chang SS, et al. Contribution of multiple chronic conditions to universal health outcomes. Journal of American Geriatric Society. 2011; 59(9): 1686-1691. PMid:21883118 http://dx.doi.org/10.1111/j.1532-5415.2011.03573.x

[4] Whitson HE, Hastings SN, Landerman LR, Fillenbaum GG, Cohen HJ, Johnson KS. Black-White disparity in disability: The role of medical conditions. Journal of the American Geriatrics Society. 2011; 59(15): 844-850. PMid:21568956 http://dx.doi.org/10.1111/j.1532-5415.2011.03401.x

[5] Sims M, Diez-Roux AV, Dudley A, et al. Perceived discrimination and hypertension among African American in the Jackson Heart Study. American Journal of Public Health. 2012; 102(S2): S258-S265. PMid:22401510 http://dx.doi.org/10.2105/AJPH.2011.300523

[6] McCollister KE, Zheng DD, Fernandez CA, et al. Racial disparities in quality-adjusted life-years associated with diabetes and visual impairment. Diabetes Care. 2012; 35(8): 1692-1694. PMid:22751960 http://dx.doi.org/10.2337/dc11-2433

[7] Baldree KS, Murphy SP, Powers MJ. Stress identification and coping patterns of patients on hemodialysis. Nurs Res. 1982; 31(2): 107-112. PMid:6926648

[8] Taylor RJ, Chatters LM, Joe S. Religious involvement and suicidal behaviors among African Americans and black Caribbeans. Journal of Nervous and Mental Disease. 2011; 199(7): 478-486. PMid:21716062 http://dx.doi.org/10.1097/NMD.0b013e31822142c7

[9] Dessio W, Wade C, Chao M, Kronenberg F, Cushman L, Kalmuss D. Religion, spirituality, and health care choices of African American women: Results of a national survey. Ethnicity \& Disease 2004; 14: 197.

[10] Polzer RL. African Americans and diabetes: Spiritual role of the health care provider in self-management. Res Nurs Health. 2007; 30(2): 164-174. PMid:17380517 http://dx.doi.org/10.1002/nur.20179

[11] Armstrong TD, Crowther MR. Spirituality among older African Americans. Journal of Adult Development. 2002; 9(1): 3-12. http://dx.doi.org/10.1023/A:1013821116396

[12] Unson CG, Trella PM, Chowdhury S, Davis EM. Strategies for living long and healthy lives: Perspectives of older African/ Caribbean-American women. Journal of Applied Communication Research. 2008; 36(4): 459-478. http://dx.doi.org/10.1080/00909880802175627

[13] Polzer RL, Miles MS. Spirituality and self-management of diabetes in African Americans. Journal of Holistic Nursing. 2005; 23(2): 230-250. PMid:15883469 http://dx.doi.org/10.1177/0898010105276179

[14] Lewis LM, Hankin S, Reynolds D, Ogedegbe G. African American spirituality. Journal of Holistic Nursing. 2007; 25(1): 16-23. PMid:17325309 http://dx.doi.org/10.1177/0898010106289857

[15] Miller WR, Thoresen CE. Spirituality, religion, and health: An emerging research field. Am Psychol. 2003; 58(1): 24-35. PMid:12674816 http://dx.doi.org/10.1037/0003-066X.58.1.24

[16] Thoresen CE, Harris AHS. Spirituality and health: What's the evidence and what's needed? Annals of Behavioral Medicine. 2002; 24(1): 3-13. PMid:12008792 http://dx.doi.org/10.1207/S15324796ABM2401_02

[17] Sermabeikian P. Our clients, ourselves: The spiritual perspective and social work practice. Soc Work. 1994; 39(2): 178-183.

[18] Spero MH. Parallel dimensions of experience in psychoanalytic psychotherapy of the religious patient. Psychotherapy: Theory, Research, Practice, Training. 1990; 27(1): 53-71. http://dx.doi.org/10.1037/0033-3204.27.1.53

[19] Burkhardt MA, Nagai-Jacobson MG. Spirituality: Living our Connectedness. Albany, New York: Delmar Thomson; 2002.

[20] Williams CB, Frame MW, Green E. Counseling groups for African American women: A focus on spirituality. The Journal for Specialists in Group Work. 1999; 24(3): 260-273. http://dx.doi.org/10.1080/01933929908411435

[21] Lee EO, Sharpe T. Understanding religious/spiritual coping and support resources among African American older adults: A mixed-method approach. Journal of Religion, Spirituality \& Aging. 2007; 19(3): 55-75. http://dx.doi.org/10.1300/J496v19n03_05

[22] Parham TA. Invisibility syndrome in African descent people. The Counseling Psychologist. 1999; 27(6): 794-801. http://dx.doi.org/10.1177/0011000099276003

[23] Paris PJ. The Spirituality of African Peoples: The Search for a Common Moral Discourse. Minneapolis, MN: Fortress Press; 1995.

[24] Stewart CF. Black Spirituality and Black Consciousness: Soul Force, Culture and Freedom in the African American Experience. Trenton, NJ: Africa World Press; 1999.

[25] Clement S. Diabetes self-management education. Diabetes Care. 1995; 18(8): 1204-1214. PMid:7587866 
[26] Clark NM, Becker MH, Janz NK, Lorig KR, Rakowski W, Anderson L. Self- management of chronic disease by older adults: A review and questions for research. Journal of Aging \& Health. 1991; 3(1): 3-27. http://dx.doi.org/10.1177/089826439100300101

[27] Leach CR, Schoenberg NE. Striving for control: Cognitive, self-care, and faith strategies employed by vulnerable black and white older adults with multiple chronic conditions. J Cross-Cult Gerontol. 2008; 23(4): 377-399. PMid:18987966 http://dx.doi.org/10.1007/s10823-008-9086-2

[28] Loeb SJ. African American older adults coping with chronic health conditions. J Transcult Nurs. 2006; 17(2): $139-147$. PMid:16595401 http://dx.doi.org/10.1177/1043659605285415

[29] Mansfield CJ, Mitchell J, King DE. The doctor as God's mechanic? Beliefs in the Southeastern United States Soc Sci Med. 2002; 54: 399-409.

[30] McAuley WJ, Pecchioni L, Grant JA. Personal accounts of the role of God in health and illness among older rural African American and white residents. J Cross-Cult Gerontol. 2000; 15(1): 13-35. PMid:14618008 http://dx.doi.org/10.1023/A:1006745709687

[31] Samuel-Hodge CD, Headen SW, Skelly AH, et al. Influences on day-to-day self-management of type-2 diabetes among African-American women: Spirituality, the multi-caregiver role, and other social context factors. Diabetes Care. 2000; 23(7): 928-933. PMid:10895842 http://dx.doi.org/10.2337/diacare.23.7.928

[32] Davis LH, Wykle ML. Self-care in minority and ethnic populations: The experience of older black Americans. In: Ory MG, DeFriese GH, eds. Self-care in Later Life: Research, Program, and Policy Issues New York: Springer Publications. 1998: 170-192.

[33] Loeb SJ, Penrod J, Falkenstern S, Gueldner SH, Poon LW. Supporting older adults living with multiple chronic conditions West J Nurs Res. 2003; 25(1): 8-29. PMid:12584961 http://dx.doi.org/10.1177/0193945902238830

[34] Utz SW, Steeves RH, Wenzel J, et al. "Working hard with it”: elf-management of type 2 diabetes by rural African Americans. Family \& Community Health. 2006; 29(3): 195-205. PMid:16775469 http://dx.doi.org/10.1097/00003727-200607000-00006

[35] Jones AC, Kwoh K, Groeneveld PW, Mor M, Geng M, Ibrahim SA. Investigating racial differences in coping with chronic osteoarthritis pain. J Cross-Cult Gerontol. 2008; 23(4): 339-347. PMid:18561011 http://dx.doi.org/10.1007/s10823-008-9071-9

[36] Hudson-Weems C. Africana Womanism: Reclaiming Ourselves. 4th ed. Troy, MI: Bedford Publishers, Inc.; 2004.

[37] Hudson-Weems C. Africana womanism: Reclaiming ourselves. 1st ed. Troy, MI: Bedford Publishers Inc.; 1993.

[38] Dove N. Defining African womanist theory. In: Mazama A, ed. The Afrocentric Paradigm. Trenton, NJ: Africa World Press. 2003: 165-183.

[39] Banks-Wallace J. Womanist ways of knowing: Theoretical considerations for research with African American women. Advances in Nursing Science. 2000; 22(3): 33. PMid:10711803

[40] Banks-Wallace J, Parks L. It’s all sacred: African American women’s perspectives on spirituality. Issues Ment Health Nurs. 2004; 25(1): 25-45. PMid:14660315 http://dx.doi.org/10.1080/01612840490249028-22

[41] Husserl E. The Crisis of European Sciences and Transcendental Phenomenology. Evanston, IL: Northwestern University Press; 1970.

[42] van Manen M. Researching Lived Experience. 2nd ed. New York: The State University of New York Press; 1997. PMid:9189983

[43] chiele JH. Human Services and the Afrocentric Paradigm. New York: Haworth; 2000.

[44] Hudson-Weems C. Africana womanism: The flip side of a coin. The Western Journal of Black Studies. 2001; 25(3): 137-145.

[45] Collins PH. Black Feminist Thought: Knowledge, Consciousness, and the Politics of Empowerment. New York: Routledge; 2000.

[46] National Center for Health Statistics. Plan and operation of the Third National Health and Nutrition Examination Survey, $1988-94$. Vital Health Stat. 1994; 32: 1-407.

[47] Boyatzis RE. Transforming Qualitative Information: Thematic Analysis and Code Development. Thousand Oaks, CA: Sage Publication; 1998. PMid:9729839

[48] Braun V, Clarke V. Using thematic analysis in psychology. Qualitative Research in Psychology. 2006; 3(2): 77-101. http://dx.doi.org/10.1191/1478088706qp063oa

[49] Aronson J. A pragmatic view of thematic analysis. The Qualitative Report. 1994; 2(1): 1.

[50] Lincoln YS, Guba EG. Naturalistic Inquiry. Thousand Oaks, CA: Sage Publications; 1985.

[51] Miles MB, Huberman AM. Qualitative Data Analysis: An Expanded Source. 2nd ed. Thousand Oaks, CA: Sage Publication; 1994.

[52] Boyd-Franklin N. Black Families in Therapy: A Multisystems Approach. New York: Guilford Press; 1989.

[53] Williams DS. Womanist theology: Black women voices (1986). In: Phillips L, ed. The Womanist Reader. New York: Routledge; 2006: 117-125.

[54] Polzer Casarez RL, Engebretson JC, Ostwald SK:. Spiritual practices in self-management of diabetes in African Americans. Holistic Nursing Practice. 2010; 244(4): 227-237.

[55] Abrums M. “Jesus will fix it after awhile”: Meanings and health. Soc Sci Med. 2000; 50(1): 89-105. http://dx.doi.org/10.1016/S0277-9536(99)00277-4 
[56] Abrums M. Faith and feminism: How African American women from a storefront church resist oppression in healthcare. ANS. 2004; 27(3): 187-201.

[57] Hall JM. Marginalization revisited: Critical, postmodern, and liberation perspective. Advances in Nursing Science. 1999; 22(2): 88-102. PMid:10634190

[58] Cervantes JM, Parham TA. Toward a meaningful spirituality for people of color: Lessons for the counseling practitioner. Cultural Diversity and Ethnic Minority Psychology. 2005; 11(1): 69-81. PMid:15727496 http://dx.doi.org/10.1037/1099-9809.11.1.69

[59] Daly A, Jennings J, Beckett JO, Leashore BR. Effective coping strategies of African Americans. Soc Work. 1995; 40(2): $240-248$.

[60] Olphen J, Schulz AJ, Israel BA, et al. Religious involvement, social support, and health among African American women on the east side of Detroit. Journal of General Internal Medicine. 2003; 18(7): 549-557. PMid:12848838 http://dx.doi.org/10.1046/j.1525-1497.2003.21031.x

[61] Williams DS. Sisters in the Wilderness: The Challenge of Womanist God Talk. Maryknoll, NY: Orbis Books; 1993.

[62] Peterson JA, Yates BC, Hertzog M. Heart and soul physical activity program: Social support outcomes. Am J Health Behav. 2008; 32(5): 525-537. PMid:18241137 http://dx.doi.org/10.5993/AJHB.32.5.8

[63] Peterson JA, Yates BC, Atwood JR, Hertzog M. Effects of a physical activity intervention for women. West J Nurs Res. 2005; 27(1): 93-110. PMid:15659587 http://dx.doi.org/10.1177/0193945904270912

[64] Samuel-Hodge CD, Keyserling TC, Park S, Johnston LF, Gizlice Z, Bangdiwala SI. A randomized trial of a church-based diabetes self-management program for African Americans with type 2 diabetes. The Diabetes Educator. 2009; 35(3): 439-454. PMid:19383882 http://dx.doi.org/10.1177/0145721709333270

[65] Dodani S, Fields JZ. Implementation of the fit body and soul, a church-based life style program for diabetes prevention in high-risk African Americans. The Diabetes Educator. 2010; 36(3): 465-472. PMid:20508263 http://dx.doi.org/10.1177/0145721710366756

[66] Carlton-LaNey I, Hamilton J, Ruiz D, Alexander SC. "Sitting with the sick”: African American women's philanthropy. Affilia. 2001; 16(4): 447-466. http://dx.doi.org/10.1177/08861090122094361 